Relations industrielles

Industrial Relations

\title{
Rezler on Automation and Employment
}

\section{Earl F. Beach}

Volume 28, numéro 4, 1973

URI : https://id.erudit.org/iderudit/028455ar

DOI : https://doi.org/10.7202/028455ar

Aller au sommaire du numéro

Éditeur(s)

Département des relations industrielles de l'Université Laval

ISSN

0034-379X (imprimé)

1703-8138 (numérique)

Découvrir la revue

Citer cet article

Beach, E. F. (1973). Rezler on Automation and Employment. Relations industrielles / Industrial Relations, 28(4), 872-878.

https://doi.org/10.7202/028455ar

Tous droits réservés @ C Département des relations industrielles de l'Universite Laval, 1973
Ce document est protégé par la loi sur le droit d'auteur. L’utilisation des services d'Érudit (y compris la reproduction) est assujettie à sa politique d'utilisation que vous pouvez consulter en ligne.

https://apropos.erudit.org/fr/usagers/politique-dutilisation/ 


\title{
REZLER ON AUTOMATION AND EMPLOYMENT
}

\author{
EARL F. BEACH
}

There can be little doubt that economists have not done a good job of analyzing the employment effects of automation. (1) (2) (3) (4) One of the results of this hiatus in theory is the tremendous controversy that continues over the subject, and policies related thereto. Labor economists have done an even worse job of using that modicum of economic theory that is easily available.

«A quick survey of a group of seven textbooks on labor economics, all books on the subject that were on the shelves of a department library at the time, showed that six of them had something to say on automation, mechanization, or technological change, but only two of them mentioned that there were other than disemployment effects on direct labor. Only one of them, for example, mentioned that some employment was required in the making of the machines that displaced the labour. »1

The new book by Julius Rezler (8) illustrates this weakness in economic theory so very well that it is interesting to examine it in some detail. First we shall detail the amount of research and study that has been going into the subject, then a brief analysis will be presented, since it seems to be needed, and then some specific criticisms of the book. All page references, unless otherwise indicated, will be to Rezler's book.

\section{FACT FINDING}

The vast program of « fact-finding 》 that has been going on during the past two decades is described on pages 65-67 : "As early as 1954, the Joint Economic Committee of the Congress charged its Subcommittee on Economic Stabilization to study automation, primarily its employment effects, and to make recommendations for legislative action if needed. During the hearings conducted by the Subcommittee in the fall of 1955 , twenty-seven prominent representatives of management, labor, government, and the academic community had stated their views on various aspects of automation such as its spread, its labor saving affects, and the need for a possible public policy .... In 1960, the same Subcommittee reinvited those who testified at the previous hearings to make known their current views concerning automation ... In the spring of 1960, hear-

* BeACH, Earl F., Department of Economics, McGill University, Montréal.

** Professor S. Ingerman brought the book to my attention and has been good enough to assist in discussion of it, but he should not be blamed for any of the statements.

1 See (4), p. 30. 
ings were being held before a House Committee on Unemployment and the Impact of Automation with the participation of twenty-one witnesses representing business, labor, and academics ... The most extensive Congressional investigation into the ramifications of the unemployment spectre was conducted by the Senate Subcommittee on Employment and Manpower in 1963 and 1964. The hearings of the so-called Clark Committee... lasted for more than eight months and involved over 150 experts, whose testimonies filled nine volumes of committee records. In 1964, selected statements and studies were published in three volumes... Since the mid-1950's, the Bureau of Labor Statistics, the research arm of the United States Department of Labor, has prepared and published a series of case studies examining changes in manpower occurring during and after the introduction of automation ... In addition... the Labor Department was also charged... in 1962 to administer a major research program ... concerning the impact of automation on human resources ... On the basis of contracts and grants issued by the Secretary of Labor since 1962, manpower research of unprecedented scope and magnitude has been carried on by universities and other organizations ... Congress felt it necessary to initiate another major investigation into the nature of manpower problems growing out of the use of automated equipment and, in 1964, enacted ... establishing a National Commission on Technology, Automation, and Economic Progress... The work of the commission, to which many experts and organizations contributed, has resulted in a great amount of new information on the relationship between automation and the labor market... Most recently, the national Advisory Commission on Civil Disorders... has paid much attention to... hard-core unemployment... which partly resulted from changes caused by automation...

Clearly there has been a tremendous amount of activity in this area in the United States; but there was some outside the country also. The Report of the Director General of the International Labor Office in 1957 was divided into two parts, one of which was wholly devoted to this question (6), and the ILO has since that time devoted a substantial quantity of resources to a continuing study of the matter. Rezler makes no mention of this and other fact-finding activities.

The problems raised by automation are indeed very complicated, and there are many conflicting interests entailed; but still, with such a massive intellectual assault on the problems, it is astounding that so much ignorance continues to exist. The existence of ignorance can be illustrated by references to Rezler's book, which seems to be characteristic of «knowledge and attitudes $\gg$ in the field.

\section{ANALYSIS}

Rezler offers a definition (pp. 6, 7) : «Functionally,... automation may be defined as the substitution of mechanical and electronic 
devices for human labor in operating, adjusting, and controlling the production process in general and the machines in particular. $>$ There is therefore in general an introduction of more expensive machinery, and the elimination of some direct operating labor. An increased amount of indirect labor is applied to maintaining, and replacing the machinery as it wears out, and some more is implied necessarily in building the machinery in the first place. The neglect of the investment aspect of automation has led to much misunderstanding of the ploblem. ${ }^{2}$

There is a tendency to dismiss the investment because it is only a transitory aspect of the problem, but it deserves a closer look. Automation destroys jobs in the sense of regimes of work activities. To what extent it causes unemployment depends upon the business conditions of the time, the qualifications of the workers, the growth of the innovating company, etc. Thus, both the investment and the unemployment are essentially temporary phenomena as regards a particular example of automation. Both are, however, permanent aspects in a dynamic macro sense.

It is possible to estimate the gain in employment which results from a given installation and the loss in employment for the operating labor, and thus estimate the net gain or loss. Results of such investigations to date show that the gains are surprisingly large relative to the losses in the great majority of cases. (3) (4)

In order to analyze the over-all result, the employment effects of automation may be divided into two groups : (1) the employment effects of investment which are almost always ${ }^{3}$ positive and are in evidence before the installation of the equipment, and (2) the employment effects of price and production changes, which are the only ones that are generally recognized. This second group can be broken down into the negative employment effects on operating labor on the one hand, and the "long run $\gg$ adjustments in employment in this and other industries which result from the price changes, and the demand and supply adjustments. Brozen (5) might call all of these effects "short run * in the sense that they can take effect quite soon, ${ }^{4}$ but generally it will take time for the prices of the product to respond and the elasticities of demand for this and related products to be felt, along with the responses in supply of materials, etc. The speed of these adjustments will depend upon market conditions, the mobility of resources, etc.

2 Cf. Doss's introductory chapter in (9) with (4) or (5) with (11). It is very interesting to note that even Cordiner (p. 23) does not list the investment effects among his positive influences.

3 If there is no additional investment in a large machine, then it is difficult to claim that there is substitution of capital for labor - there is only technological change which reduces both capital and labor.

4 Brozen's analysis is weakened by his inadequate appreciation of the significance of investment, and hence he over-estimates the rapidity of such responses. 


\section{CRITICISM}

(1) Rezler points out (pp. 14,15) that there is a difference between micro and macro information, and also according to the period of time ; but there seems to be no awareness of the investment effects and the analysis that results therefrom, as above.

(2) Chapter 3 is of most interest to us. It bears the title : "Employment, Unemployment, and Automation. 》 The first pages (21-4) outline the general pros and cons : «Two distinct schools of thought are represented in this controversy. The first school, contending that automation causes little or no unemployment, is made up mostly of representatives of management, conservatives, and economists of the neoclassical brand. The second group, comprised mainly, but not exclusively, of labor leaders, liberals, and institutional economists, is convinced that automation is going to cause unemployment of major proportions. »

It is to be noted that there are economists on both sides of this important issue. Surely this is a matter which economic theory ought to be able to settle. A beginning has been made.

There is no dispute that technological unemployment can occur ; witness the meat packing industry (p. 28). Such unemployment tends to be rather specific geographically and industrially. It can be temporary if alternative employment is found fairly soon, or it can last a considerable time if business conditions are not good in those areas.

It is however very difficult to measure the total quantity of technological unemployment at any time because there are other kinds of unemployment which differ very little from it. For example, when a new product competes successfully with another the unemployment effects on the losing product will show up on a business downturn and will not be easy to distinguish from simple cyclical unemployment or from a change in tastes.

The quarrel is really about the net effects on employment ; that is whether positive or negative effects predominate. Economists have concerned themselves very much with the long run effects and have convinced themselves that long run benefits compensate for short run real costs. 5 These are the «economists of the neoclassical brand. 》 On the other side are the «institutional economists» along with «labor leaders and liberals 》 who are «convinced that automation is going to cause unemplayment of major proportions. » For these latter it is in order to ask some questions : 
(1) What is the basis for not accepting the results of over a hundred years of economic analysis of classical and neoclassical economists inadequate though it be ?

(2) The use of the future tense is significant. "Automation» can be said to have been with us for about a quarter of a century. When is this unemployment effect going to show itself ?

(3) It is interesting that the recent trend towards greater unemployment was forced by control measures by the monetary authorities and the government, despite a growing tendency towards automation! It begins to appear as if automation does not cause net unemployment, but a net expansionary effect, with pockets of unemployment of particular kinds of labor in particular places. This is what the newer theory suggests.

(3) In Chapter 11 Rezler gives «The Views of American Unionists on Automation ». They are very interesting. First, we find Mr. Meany changing his mind (pp. 140,141) or, like some others, presenting different views in different circumstances. Or special interest is the information obtained from surveys. Mr. Rezler seems puzzled as to why workmen have more positive attitudes about automation than do labor leaders, especially local labor representatives (p. 143). This may be because the union officers are conditioned to worry noisily, but there may be more, and a little economics should help to put it in perspective.

Labor leaders can be in a difficult situation. Their positions may in some cases be more vulnerable than those of the workers. The individual workmen may not lose any employment or even income, while the union local may face extinction or at least, difficult circumstances. This is surely illustrated by the locomotive firemen.

The craft unions especially have much to fear from automation which can endanger their economic base, and this danger is greatest when the union is organized along narrow craft lines. One should expect, therefore, differences among union leaders, depending upon their situation, and we might have expected Mr. Rezler to find such differences. The author, however, concludes (p. 142) that «The ambivalent reaction of national union leaders can be explained only in terms of the American value system ....»!

There can be little doubt that labor as a whole, and labor unions have a great deal to gain through automation, though the damage to individual unions can be real. The importance of adjustment procedures cannot be overestimated, and they require understanding by all those concerned. The ignorance displayed is frightening.

(4) Part V deals with industrial relations, and in particular with collective bargaining about questions of technological change. Confining 
ourselves simply to the implications of the analysis offered above, it should be clear that «other parties 》 do have an interest in such collective bargaining, in addition to the general «public interest 》 which is affected by strikes. For example, if the pace of automation is slowed by agreements or by legislation, ${ }^{6}$ the capital goods industries are certainly affected. This is not to say that the pace should not be slowed so as to arrange a better handling of the human problems, but merely that the implications should be fully understood.

On questions of costs of re-training and re-location, it should not be merely a matter of splitting the profits that result from the improvement in productivity, or "treating re-location as part of the total capital cost. ( (p. 177) Other parts of the economy have already benefitted through the investment and its re-percussions. They should be concerned if the process is slowed up, and they are in a position to share some of the burden.

The government is seen, by Rezler (p. 178) to be stepping in to help with re-training programs when the program is large and extends over a substantial area; but there is another important reason why the government is the agency to assist, and it should assist liberally in these changes. Its tax revenues benefit; employment in general is improved; it can and should assist in many ways, not through default, but because society is interrelated in this fashion. ${ }^{7}$ This is not to say that if the innovating company wishes to take on the obligation it should not do so, for it may well be in the interests of a better work force to do much of its own re-training, and to reassure the work force with the knowledge that it will re-locate them ect. But to limit the improvement activities to the collective bargaining table is to close one's eyes to some of the realities of the economic system.

It is in order to question the «autonomy » of the bargaining table in another way. When technological change is taking place rapidly, the stronger companies force the pace. They can pay higher wages, and in doing so, stand a chance of getting better quality workmen. They put pressure on other companies, and may cause a speed-up in the pace of automation in the industry. This increases the obsolescence of old plants, endangers the finances of weaker companies, and may reduce the total work force in the industry. What goes on at one bargaining table has important implications for other bargaining tables.

There are many who wish to keep government out of such bargaining sessions. It may be possible to devise other systems which do take into account the economic realities of the situation without the government sitting down at the table; but the realities should be recognized.

\footnotetext{
6 See (7), p. 7, 8 .

7 Cf. (7), p. 10, 12.
} 


\section{CONCLUSION}

Mr. Rezler does a good reporting job, but his lack of interest in economic analysis and its implications contributes to the spread of ignorance and uncertainty. Surely we have learned by this time to distinguish between people who have vested interests, like management and union leaders, and others who are not so committed. When vested interests are recognized, their views can be discounted. This is not to say that they are not important; it behoves these people to make their points with the utmost vigor and ingenuity so that no aspect of these important problems is overlooked. Those without strong vested interests should have a more intellectual approach to the problems, and it is important that they use a little more economic theory to lessen the confusion.

\section{REFERENCES}

1. E. F. BEACH, «La théorie économique de l'automation », Relations Industrielles-Industrial Relations, July 1967, 22, pp. 400-410.

2. —L La mécanisation et l'emploi dans la province de Québec », Relations Industrielles - Industrial Relations, Nov. 1968, 23, pp. 661-666.

3. — How Automation Increases Employment», Canadian Business, May 1970, pp. 62-64.

4. _- «Office Automation and Employment», The Canadian Banker, May/ June, 1970, pp. 30-33.

5. Yale BROZEN, Automation and Jobs, Selected Papers No. 18, published by the Graduate School of Business of the University of Chicago.

6. INTERNATIONAL LABOR OFFICE, Report of the Director-General, Part I : Automation and Other Technological Developments, Labor and Social Implications, Geneva, 1957.

7. - Report of the Meeting of Experts in Programmes of Adjustment to Automation, Geneva, 1967.

8. Julius REZLER, Automation and Industrial Labor, Random House, New York, 1969.

9. Arthur M. ROSS, ed., Unemployment and the American Economy, N. Y., 1964.

10. J. A. SCHUMPETER, History of Economic Analysis, Oxford, 1954.

11. Ben SELIGMAN, Most Notorious Victory, Collier MacMillan, 1966. 